\title{
Personalized Breast Cancer Risk Assessment: Incorporation of Genetic and High-Risk Factors on Breast Cancer Risk and Management
}

\author{
Jennifer M. Siettmann*, Banu Arun², Justin Gasparini', Lida A Mina ${ }^{3}$ \\ ${ }^{1}$ Genetic Counselor, Banner MD Anderson Cancer Center, Gilbert/Phoenix, AZ \\ ${ }^{2}$ Professor Breast Medical Oncology, Co-Director Clinical Cancer Genetics \\ Executive Director Cancer Genetics MD Anderson Cancer Networks, University of Texas MD Anderson Cancer Center, Houston, TX \\ ${ }^{3}$ Breast Medical oncology, Co-Director Comprehensive Breast Program, Banner MD Anderson Cancer Center \\ Adjunct Clinical Assistant Professor, University of Texas MD Anderson Cancer Center, Houston, TX
}

*Corresponding author: Jennifer Siettmann MS, CGC Certified Genetic Counselor Banner MD Anderson Cancer Center 2940 E. Banner Gateway Drive, Suite 450 Gilbert, AZ 85234

Ph: (480) 256-3642 Fax: (480) 256-4726 E-Mail: jennifersiettmann@bannerhealth.com

Received: 20.10.2021 Accepted: 30.11 .2021

\section{Rezumat}

Cancerul mamar continuă să fie al doilea cel mai frecvent diagnosticat tip de cancer în rândul femeilor din întreaga lume şi prima cauză de cancer în rândul femeilor din Statele Unite. Din păcate, reprezintă principala cauză a deceselor provocate de cancer la femei, $14 \%$ din totalitatea deceselor provocate de cancer, în general, fiind atribuite neoplasmului mamar. În ultimul deceniu, metodele de screening s-au dezvoltat, iar investigațiile imagistice sunt în continuă îmbunătățire. $\mathrm{Cu}$ toate că mamografiile de screening rămân singura modalitate de a îmbunătăți rata de supraviețiire în cancerul mamar, investigații precum imagistica prin rezonanță magnetică sau mamografia digitală cu tomosinteză, încep să câştige amploare. Acum, mai mult ca niciodată, furnizorii de îngrijiri medicale trebuie să identifice populația aflată la risc de a dezvolta cancer de sân, astfel încât să poată oferi o abordare de screening adaptată gradului de risc. În acest articol scoatem în evidență factorii de risc ai neoplasmului mamar şi rezumăm modalitățile recent implementate de evaluare a riscului de cancer mamar al unei femei. De asemenea, sintetizăm noi strategii de testare genetică şi rezultatul lor în prevenirea cancerului de sân. $\mathrm{Nu}$ în ultimul rând, oferim o abordare personalizată a femeilor cu predispoziție genetică, precum şi celor care prezintă un risc crescut, dar care nu au mutații genetice. Scopul este de a identifica femeile expuse unui risc crescut şi de a perfecționa abordările personalizate de screening pentru cancerul mamar. 
Cuvinte cheie: evaluarea riscului genetic, cancer de sân cu risc ridicat, screening pentru cancerul de sân, cancer de sân genetic, testare genetică, model de risc de sân (cancer), genă de sân

\section{Abstract}

Breast cancer remains the second most diagnosed cancer in women worldwide and the number one cause of cancer in women in the United States. It is unfortunately the primary cause of cancerrelated deaths among women, with $14 \%$ of all cancer deaths attributed to it. Over the past decade, screening methods have matured, and imaging modalities are continuously improving. Screening mammograms remain the only modality that have been shown to improve breast cancer survival, however, more modalities like MRI, abbreviated MRI, and CT mammography are gaining in momentum. Now more than ever, providers need to identify the patient population that is at an elevated risk for breast cancer to offer them a personalized screening approach specific to their empiric risk. In this paper we shed light on risk factors of breast cancer and summarize risk assessment tools that have been recently incorporated in assessing a woman's risk of breast cancer. We also summarize new genetic testing strategies and their implications in prevention of breast cancer. And finally, we offer a personalized approach to management of women with agenetic predisposition as well as to women at elevated risk but without a genetic mutation. The hope is to identify women at increased risk and perfect a "personalized screening approach" for breast cancer.

Key words: genetic risk assessment, high risk breast cancer, breast cancer screening, genetic breast cancer, genetic testing, breast (cancer) risk model, breast gene

\section{Background}

Our understanding of breast cancer disease and treatment has improved dramatically since it was first recorded in ancient Egypt. Notable surgical advancements, improved chemotherapy and radiation options, and incorporation of genetic tumor markers have all aided in the treatment and management of breast cancer. Unfortunately, despite these advancements, breast cancer is still very prevalent. Breast cancer remains the second most diagnosed cancer in women worldwide and the number one cause of cancer in women in the United States. It is unfortunately the primary cause of cancer-related deaths among women, with $14 \%$ of all cancer deaths attributed to it $(1,2)$. Prevalence peaked in the mid-1980s -1999 when screening practices became commonplace. In 1999, the incidence of breast cancer dropped, which was attributed to reaching a plateau in screening as well as a decrease in hormone replacement therapy usage (3). Over the past decade, screening methods have matured, and imaging modalities are continuously improving. Screening mammograms remain the only modality that have been shown to improve breast cancer survival (4), however, more modalities like magnetic resonance imaging (MRI), abbreviated MRI, and computerized tomography (CT) mammography are gaining in momentum $(5,6)$. Now more than ever, providers need to identify the patient population that is at an elevated risk for breast cancer to offer them a personalized screening approach specific to their empiric risk.

\section{Risk Factors and Risk Stratification}

There are numerous risk factors that contribute to an increased risk for breast cancer. Age remains the number one independent risk factor, but many others have been implicated. Other intrinsic risk factors such as gender, race, and genetic predisposi- 
tion are highly linked to a woman's predisposition. The Surveillance, Epidemiology, and End Results (SEER) Program database shows that women are a hundred times more likely to develop breast cancer than men. European ancestry has also been reported as an independent risk factor for breast cancer, with rates higher than in African American women. Estrogen exposure, both intrinsically as well as externally, has also been accepted as a cause for increased risk. But genetics remain the most feared risk factor, despite the fact that only $10 \%$ of breast cancer is attributed to a pathogenic variant $(\mathrm{PV})(7,8)$.

For the past two decades, efforts have been made to incorporate these risk factors into different models to identify women at an elevated risk for breast cancer. The models have been divided into two categories of empirical and genetic risk prediction models. Radiologists, oncologists, and genetic counselors have joined efforts to stratify patients into average risk, high risk, or higher risk categories based on these models. Once high-risk or higher risk patients are identified, they are offered preventive therapy and a personalized approach to screening.

\section{Aims}

In this paper, we will describe how to risk stratify women without a personal history of breast cancer, and explore the available tools and models used to assess a woman's individual risk profile with a specific overview on multigene panel testing. We will also summarize the different levels of genetic risk, their implications, and the limitations of genetic testing.

\section{Risk Assessment and Empiric Risk Models}

Many characteristics about a women's personal and family history have been identified that influence her risk for breast cancer. Statistical models have been developed which allow clinicians to combine these characteristic data points and quantify a woman's lifetime risk for breast cancer. Each model uses a particular set of patient characteristics, ranging from the commonly included data points like reproductive history to less common data points like breast density. The appropriateness of each model depends on the individual. Four of the most commonly used models are Claus, Gail, Tyrer-Cuzick (TC), and BRCAPro. The first three models exclude those with a personal history of invasive breast cancer or ductal carcinoma in situ (DCIS). These risk models are not appropriate for individuals who have tested positive for a hereditary cancer predisposition such as BRCA1/2. Comparisons between these models, including a breakdown of their strengths and limitations, are displayed in Table 1.

The Claus model was developed from casecontrol study data and establishes a woman's risk based on evidence for a rare autosomal dominant inherited cause. Claus only takes into consideration a woman's family history of breast cancer (9). It consists of a series of tables used to calculate risk using basic math. This model can be easily calculated for anyone in a family if you know the woman's age (starting age 29) and the family history of breast cancer. However, it is limited to firstand second-degree relatives and only accounts for up to two total affected family members. It does tend to underestimate risk (10). There was an effort to improve on these limitations with "Claus extended" that includes additional family members with breast cancer, bilateral breast cancer, and family history of ovarian cancer (11).

The Gail model is also known as the Breast Cancer Risk Assessment Tool (BCRAT) and is based on breast cancer screening studies of women along with SEER data. This model largely uses data of white women, so it performs best for estimating the risk for white women. Smaller sets of data from women of African American, Hispanic, and Asian/Pacific islander ancestry were included. Computing a Gail model score is quick and can be performed easily online and includes the patient's personal history: including reproductive history, breast biopsies, and family history of breast cancer. However, family history is limited to just the number of affected first- 
Table 1. Summarized risk model strengths, limitations, and performance

\begin{tabular}{|c|c|c|c|}
\hline Risk Model & Strengths and Uses & Limitations & Overall Performance* \\
\hline Claus & $\begin{array}{l}\text { - Simple to calculate based } \\
\text { on family history } \\
\text { Uses } \\
\text { - Determine eligibility for MRI } \\
\text { screening }\end{array}$ & $\begin{array}{l}\text { - Family history only, maximum } \\
2 \text { relatives } \\
\text { - Only } 1^{\text {st }} \text { and } 2^{\text {nd }} \text { degree relatives } \\
\text { considered } \\
\text { - Minimum age } 29 \text { years old } \\
\text { - Underestimates risk (10) }\end{array}$ & $\begin{array}{l}\bullet \mathrm{O} / \mathrm{E}=1.69^{\star * *} \\
-\mathrm{PPV}=.039^{\star * \star} \\
-\mathrm{NPV}=0.975^{\star * *} \\
\text { (Better PPV, lower NPV than other } \\
\text { models among women with family history) }\end{array}$ \\
\hline Gail & $\begin{array}{l}\text { - Personal data and limited } \\
\text { family history } \\
\text { Uses } \\
\text { - Determine eligibility for } \\
\text { chemoprevention }\end{array}$ & $\begin{array}{l}\text { - Only asks number of affected } \\
\text { first degree relatives } \\
\text { - Minimum age } 35 \text { years old }\end{array}$ & $\begin{array}{l}-0 / E=0.94 \\
\text { - } P P V=0.029 \\
\text { - } N P V=0.987\end{array}$ \\
\hline $\begin{array}{l}\text { Tyrer-Cuzick } \\
\text { (version 8) }\end{array}$ & $\begin{array}{l}\text { - Breast cancer risk and } \\
\text { mutation probability calculated } \\
\text { - Most personal characteristics } \\
\text {-e.g. breast density, BMI } \\
\text { - Minimum age } 19 \\
\text { - Accounts for male breast cancer } \\
\text { family history } \\
\text { - Affected and unaffected family } \\
\text { considered in calculation } \\
\text { Uses } \\
\text { - Determine eligibility for MRI } \\
\text { screening }\end{array}$ & $\begin{array}{l}\text { - Many data inputs mean more } \\
\text { time to calculate }\end{array}$ & $\begin{array}{l}\text { - } 0 / E=0.84 \\
\text { - } P P V=0.026 \\
\text { - } N P V=0.987\end{array}$ \\
\hline BRCAPro & $\begin{array}{l}\text { - Breast and ovarian cancer risk } \\
\text { - BRCA1/2 mutation probability } \\
\text { - Affected and unaffected family } \\
\text { considered in calculation } \\
\text { - Accounts for male breast cancer } \\
\text { family history } \\
\text { Uses } \\
\text { - Ovarian cancer risk estimation }\end{array}$ & $\begin{array}{l}\text { - Personal info limited to age } \\
\text { - Only } 1^{\text {st }} \text { and } 2^{\text {nd }} \text { degree relatives } \\
\text { considered }\end{array}$ & $\begin{array}{l}\text { - O/E: } 0.94 \\
\text { - } P P V=.026 \\
\text { - NPV }=.987\end{array}$ \\
\hline
\end{tabular}

$\mathrm{O} / \mathrm{E}=$ ratio of observed to expected cases; $\mathrm{PPV}=$ positive predictive value; NPV = negative predictive value * performance data from McCarthy et al 2020 (13) unless otherwise noted

$* \star \star$ Claus data only comparable to other models in sub-analysis by family history $(n=11,873)$

degree family members she has. A personal history of lobular carcinoma in situ (LCIS) rules out the use of the Gail model. The Gail model provides a 5-year risk as well as a lifetime risk estimate. The 5-year risk is the only validated risk for the Gail model and it is used to identify women who would benefit from chemoprevention (12).

The Tyrer-Cuzick (TC) risk model, also known as International Breast Cancer Intervention Study or IBIS, estimates breast cancer risk presuming the existence of a dominant low penetrance genetic factor influencing breast cancer risk. The TC model calculates a 10-year risk and lifetime risk using more data points than both the Claus and Gail models, including the woman's height and weight, hormonal and reproductive history, as well as breast density and family history out to third-degree relatives (13). This model can be used for women with a history of LCIS or atypical ductal hyperplasia (ADH). Another strength of this model is that it considers both affected and unaffected first-, second-, and third-degree relatives. Results of BRCA1/2 genetic testing for the patient or family can also be incorporated. It is more time consuming to input data to calculate a TC score than Gail and Claus, but shorter web-based versions are available. TC will 
output a simplified pedigree and a graph comparing the calculated risk over time compared to population risk. The TC model tends to slightly over-estimate risk, particularly for women with breast biopsy findings such as atypical hyperplasia.

Polygenic risk scores (PRS) for breast cancer are determined by modifying a patient's calculated TC with the results of multifactorial genetic testing. A PRS combines many small, common risk variants found in genome-wide association studies (GWAS) into a multiplier such as 1.1 or 0.8 . For example, a woman with a $15 \%$ TC may also have a PRS of 0.9 . To calculate her lifetime risk for breast cancer, the genetic testing lab will multiply $0.15 * 0.9$ to get a final risk estimate of 0.135 , or $13.5 \%$, which would suggest these common genetic variants are actually putting her at a lower lifetime risk than TC alone. However, where a TC calculated risk of breast cancer is useful clinically to recommend breast MRI for those at elevated risk, a PRS is not validated to recommend for or against screening as high risk at this time. PRS are only valid for women of only European background as the current common genetic variants are European-specific variants. Further research and validation need to be done for this to be available for a diverse set of women (14).

The fourth model, BRCAPro, is one of a suite of models that are used to calculate the chance for an inherited cause for cancer. A woman's chance to have inherited the BRCA1/2 pathogenic variant is calculated using data about her family history of breast and ovarian cancer and includes affected and unaffected family. BRCAPro will also provide lifetime and 5-year risks for breast and ovarian cancer based on the calculated BRCA1/2 probability. BRCAPro is a part of the CancerGene software package which includes -Pro models for calculating Lynch syndrome, pancreatic, and melanoma gene probabilities (15).

The above risk models have been compared over time in a variety of settings and demographics. One such comparison in a large mammography cohort of more than 42,000 women in the United States with mean follow-up of 6.7 years showed similar predictive ability between Gail, TC, and BRCAPro with worse performance using Claus, seen in Table 1. The study shows comparative performance in the general population setting. The models that include more detailed family history information tend to perform better in a high-risk population where one would find more reports of affected family members (10).

Multiple other models exist for calculating empiric risk, which more accurately address an individual woman's characteristics. The Breast and Ovarian Analysis of Disease Incidence and Carrier Estimation Algorithm (BOADICEA), which was developed in the United Kingdom, is the only tool that will estimate contralateral breast cancer risk. And due to most models having their largest sets of data based on white women, specific models focusing on other ethnic/racial backgrounds also exist. The Black Women's Health Study Model estimates African American women's breast cancer risk (16). Other risk models may underestimate black women's breast cancer risk.

There is no one model that fits all situations. Providers need to choose a risk model based on the data they have and what risk they are assessing. Rather than relying on a single model for all, using and comparing multiple models will often give a better prediction of risk.

\section{Hereditary Breast Cancer}

Some women are at a higher risk for breast cancer because they have an inherited cancer syndrome. Hereditary breast cancer syndromes occur due to PVs in specific genes that disrupt the body's natural DNA damage repair mechanisms. One such syndrome is Hereditary Breast and Ovarian Cancer syndrome (HBOC) caused by PVs in the BRCA1 and BRCA2 genes involved in homologous recombination DNA repair (Table 2). Women with an inherited breast cancer syndrome (sometimes referred to as a genetic predisposition) are managed based on the gene's specific associated cancer 
Table 2. Management for breast cancer genes summarized ${ }^{\star}$

\begin{tabular}{|c|c|c|c|}
\hline Gene/Syndrome & Cancer Risks & Screening Recommendations* & Risk Reduction Options* \\
\hline $\begin{array}{l}\text { BRCA1/2 } \\
\text { Hereditary Breast } \\
\text { and Ovarian Cancer } \\
\text { Syndrome (HBOC) }\end{array}$ & $\begin{array}{l}\text { Breast } \\
\text { Ovarian } \\
\text { Prostate } \\
\text { Pancreatic } \\
\text { Melanoma }\end{array}$ & $\begin{array}{l}\text { Annual breast MRI at } 25 \\
\text { Annual mammogram at } 30 \\
\text { Pancreas endoscopic ultrasound or } \\
\text { MRCP' if close family history present } \\
\text { Melanoma, no specific technique }\end{array}$ & $\begin{array}{l}\text { Risk reducing mastectomy, } \\
\text { consider } \\
\text { Risk reducing BSO at } 35-40\end{array}$ \\
\hline $\begin{array}{l}\text { TP53 } \\
\text { Li Fraumeni Syndrome (LFS) }\end{array}$ & $\begin{array}{l}\text { Breast } \\
\text { Adrenocortical carcinoma } \\
\text { Central nervous system } \\
\text { Sarcoma } \\
\text { Gastrointestinal } \\
\text { Hematologic }\end{array}$ & $\begin{array}{l}\text { Annual breast MRI at } 20 \\
\text { Annual mammogram at } 30 \\
\text { Biannual comprehensive exam } \\
\text { Colonoscopy every } 2-5 \text { years } \\
\text { Annual dermatology exam at } 18 \\
\text { Annual MRI (whole body \& brain) }\end{array}$ & $\begin{array}{l}\text { Risk reducing mastectomy, } \\
\text { consider }\end{array}$ \\
\hline ATM & $\begin{array}{l}\text { Breast } \\
\text { Pancreatic } \\
\text { Prostate }\end{array}$ & $\begin{array}{l}\text { Annual mammogram \& MRI at } 40 \\
\text { Pancreas endoscopic ultrasound or } \\
\text { MRCP' if close family history present }\end{array}$ & Based on family history \\
\hline CHEK2 & $\begin{array}{l}\text { Breast } \\
\text { Colorectal } \\
\text { Prostate }\end{array}$ & $\begin{array}{l}\text { Annual mammogram \& MRI at } 40 \\
\text { Colonoscopy at } 40 \text {, every } 5 \text { years }\end{array}$ & Based on family history \\
\hline
\end{tabular}

*See NCCN Guidelines for full up-to-date recommendations

MRCP - magnetic resonance cholangiopancreatography

risks. For example, a high risk for lobular breast cancer and gastric cancer are associated with Hereditary Diffuse Gastric Cancer syndrome (CDH1 gene). Much like women who are identified to be at high risk due to empiric risk models, women with a genetic predisposition are eligible for preventative medical interventions like increased screening or surgical prevention. These management plans are discussed in more detail later in the chapter. Unlike risk model calculations, genetic findings can also alter the treatment plan for women with a personal history of cancer.

Patients with hereditary breast cancer are initially detected by looking for common signs in their personal and family health history. These signs include: a woman's cancer history, the pattern of cancers in her family, and ages at diagnosis. The National Comprehensive Cancer Network (NCCN) Guidelines publish and update genetic testing criteria to help guide clinicians on who should be offered genetic testing. Table 3 provides a summary of current referral guidelines for high-risk breast cancer genes for individuals who should be referred to a genetic counselor for a more thorough discussion on genetic testing. Other criteria exist for other cancer syndromes, like
Lynch syndrome and Familial Adenomatous Polyposis. For more detailed and updated criteria, please view the NCCN Genetic/ Familial High-Risk Assessment: Breast, Ovarian, and Pancreatic guidelines (17).

Referrals for genetic assessment are made based on a significant personal and/or family history of cancer, including primary cancer site, age at diagnosis, repetitions of certain cancers within a family, or suggestive combination of tumors such as breast and ovarian cancer. Referrals should also be made for any individual who has a family member with a confirmed mutation in a cancer gene. Additional reasons for referral can include finding a somatic genetic variant suggestive of a cancer predisposition syndrome or to determine targeted treatment eligibility (like poly-adenosine diphosphate ribose polymerase (PARP) inhibitors).

Pretest genetic counseling is the ideal approach for patients considering hereditary cancer genetic testing. Genetic counselors assess the medical factors that indicate testing along with the psychosocial and technical aspects of hereditary cancer. Genetic counselors are also trained to navigate the new advancements in genetic testing, provide education 
Table 3. Genetics referral indications ${ }^{\star * *}$ - individuals at higher risk for a breast cancer predisposition

\begin{tabular}{|c|c|}
\hline Personal History (current or prior) & Criteria \\
\hline $\begin{array}{l}\text { Breast Cancer } \\
\text { (includes DCIS, lobular, and ductal breast cancer) }\end{array}$ & $\begin{array}{l}\text { - Triple negative breast cancer at any age } \\
\text { - Two breast primaries in an individual } \\
\text { - Breast cancer in }>2 \text { close* relatives } \\
\text { - Diagnosed }<45 \text { in self or a close* relative } \\
\text { - Male breast cancer in self or a close* relative } \\
\text { - Ashkenazi Jewish ancestry } \\
\text { - Combined with a personal/family history of ovarian, pancreatic, } \\
\text { metastatic prostate (or Gleason }>7 \text { ), colon, or uterine cancer }\end{array}$ \\
\hline Lobular Breast Cancer & $\begin{array}{l}\text { - Diffuse gastric cancer in self or close* family member } \\
\text { - Any of the above criteria for breast cancer }\end{array}$ \\
\hline Ovarian Cancer & - Diagnosed at any age \\
\hline Pancreatic Cancer & - Diagnosed at any age \\
\hline Prostate Cancer (Gleason $\geq 7$ ) & $\begin{array}{l}\text { - Metastatic } \\
\text { - Combined with a personal/family history of ovarian, pancreatic, or breast } \\
\text { cancer }\end{array}$ \\
\hline $\begin{array}{l}\text { Unaffected or diagnosed with a different } \\
\text { type of cancer (e.g. colon, uterine) }\end{array}$ & $\begin{array}{l}\text { - Close* family member who meets any of the above criteria } \\
\text { - May meet genetic testing criteria for other non-breast cancer associated } \\
\text { genes (should refer to NCCN Guidelines or clinical guidelines) }\end{array}$ \\
\hline \multicolumn{2}{|c|}{ Individuals with a known mutation in any relative should pursue genetic testing regardless of the above criteria } \\
\hline
\end{tabular}

on multi-gene panels, and select the most appropriate multi-gene panel for the patient.

\section{Multi-Gene Panels: Benefits and Challenges}

Current cancer genetic testing strategies utilize next-generation sequencing (NGS) panels to analyze multiple genes associated with hereditary cancer. These multi-gene panels (MGPs) are now considered the gold standard for cancer genetic testing (17) as they allow for affordable, quick, objective, and accurate sequencing and deletion/duplication analysis of multiple genes associated with hereditary cancer (18-21). Prior to MGP's debut in 2013, cancer genetic testing relied on a single gene sequencing approach through Sanger sequencing. Sequencing for BRCA1/2 genes began in 1996, and sequencing for other genes like TP53, CDH1, and PTEN followed soon after (22). If patients met criteria for more than one gene (i.e. BRCA1/2 and TP53), then two separate tests needed to be ordered by clinicians, which wasn't always covered by insurance. This led to incomplete testing for patients who may have had PVs in genes outside of the traditionally tested BRCA1/2 genes. The ramifications of this limited testing are still seen today. Patients may report to their clinicians that they have had genetic testing, but this testing may not be complete. In these situations, clinicians need to find copies of their patient's results to assess if updated testing is needed. In previously negative BRCA1/2 patients that have had updated genetic testing with an MGP, about $11 \%$ of them test positive for a different gene, so there is benefit in retesting these patients (23).

The advent of MGPs brought with them new challenges and ethical considerations for genetic testing. Clinicians expressed concerns about informed consent, identifying PVs in newly discovered genes that didn't have medical management guidelines, and finding incidental PVs in a gene not supported by the patient's family history $(21,22,24)$. In the early years of MGPs, clinicians struggled with when to offer MGPs as there were no national or insurance guidelines for MGP testing: some clinicians chose not to offer MGPs and some were only offering them for patients with significant family histories or for patients 
who clearly met criteria for more than one syndrome (24). Clinicians also expressed concern over an increased rate of finding a variant of uncertain significance (VUS) and the complications interpreting these results, and this played a role in clinician's choices about how large of a panel to order $(24,25)$. However, sufficient pre-test genetic counseling and patient engagement in the testing process can help alleviate some of these concerns with MGPs (26). MGPs have also varied in size from year to year - some initial cancer MGPs contained as few as 6 genes, whereas now cancer MGPs can approach up to 100 genes which means patients that had an early MGP may not have received complete testing for all the clinically indicated cancer genes. And while there are now insurance and national criteria for MGP testing, most of these criteria use older BRCA1/2 and Lynch criteria, which does not capture the phenotype of many of the other genes on MGPs, however this is improving $(17,27)$.

However, MGPs have proven to be beneficial for the cancer genetics field. MGPs have expanded access for patients by bringing down the cost of genetic testing and allowing patients to be tested for more genes. About $50 \%$ of PVs found on MGPs are in genes other than BRCA1/2, which would have been missed on traditional sequencing methods $(26,27,28)$. MGPs have increased the sample size of patients tested for previously underresearched genes, which has led to better classification of cancer risks associated with PVs in these genes $(29,30)$. MGPs have also led to more accurate cancer risk estimates for previously established genes like $\mathrm{CDH} 1$ and TP53 as patients with a wider variety of family histories are now being found with PVs in these genes $(30,31)$. Cancer genetics has long relied on accurate family histories to determine genetic testing, however these have been shown to be unreliable as patients do not always accurately recall their family history $(32,33)$ and is biased towards people with close familial ties. Testing for a wide array of genes helps alleviate the need for an accurate family history, though family history information is still useful for interpreting the results of MGPs.

\section{Target Genetic Testing Population}

In cancer genetics, it is most helpful to initiate genetic testing with a person who has already been diagnosed with cancer. This person is the most informative person to test, because if a $\mathrm{PV}$ is responsible for the cancers in the family, there is a high likelihood it will be found in someone with cancer. This raises some concerns over what to do with an unaffected patient who presents requesting genetic testing based on a family history of cancer. In an ideal world, the clinician would recommend the patient contact their affected family member to pursue genetic testing. In reality, though this process becomes complicated and fraught with problems. The family member with cancer may have died or may be uninterested or unavailable for testing. However, waiting to test someone who is already diagnosed with cancer may defeat the purpose of preventative testing (34). Our practice's anecdotal experience has found that the likelihood an affected family member will pursue testing is low, as is the likelihood that the unaffected patient will return if his/her attempts are unsuccessful. This approach also highlights ethnic and socio-economic-status (SES) disparities in the genetic testing process, as patients with a low SES background or patients from minority groups may have more difficulties returning for a second appointment or getting a family member tested than other populations $(35,36,37)$. Our practice's current approach is to test the patient if he/she meets criteria and is interested to avoid losing the patient to follow-up and to prevent furthering the ethnic and SES disparities already prevalent in genetic testing.

\section{Genetic Testing Results and Implications}

There are four different results that can be found on genetic testing. A negative result means that no PVs or inconclusive variants are found in any of the genes tested. In a 
patient who has a family history of a known $\mathrm{PV}$, this is considered a true negative result the family history of cancer is explained by the PV found in the family members, and the patient doesn't have it, so she is not at an increased risk for cancer. In any other patient, this is considered an uninformative negative result - the personal and/or family history of cancer is still unexplained, and that patient should still be managed based on empiric risk models.

A positive result means that a PV has been found in one or more genes. The genetic testing laboratory has determined this PV affects gene function and increases the risk for specific cancers associated with this gene. These PVs typically have a $50 \%$ chance of being passed on in families, and most PVs have screening and preventative recommendations that can be done to manage that cancer risk. A carrier result means that a $\mathrm{PV}$ has been found in one or more autosomal recessive genes. Being a carrier does not increase the risk to develop cancer, however if two carriers have a child, there is a $25 \%$ chance both parents pass on their PV to a child, who would be at an increased risk for cancer.

A VUS is a variant that is found in one or more genes, however it's uncertain at the time of testing whether this variant is truly associated with disease (like a PV) or whether it's a benign variant (called a polymorphism). These are considered uninformative and clinically negative results. Current guidelines state that clinicians should not make medical management recommendations based on a VUS result (38). Laboratories do eventually reclassify VUS results, and clinicians should recontact their patients if a reclassification report is sent to them by the genetic testing laboratory, especially if it's upgraded to a positive result $(38,39)$. Clinicians should also check with a database like ClinVar to verify how different laboratories classify a VUS result: one laboratory might classify it as a PV while another might call it a VUS. Clinicians should be aware if a VUS has inconsistent classifications amongst laboratories and determine how to manage those results accordingly. VUS results have long caused confusion in the realm of genetic testing with clinicians not familiar with genetic testing $(40,41)$. Improperly disclosed VUS result can cause some patients psychological distress, so clinicians should provide sufficient pre- and post-test counseling on VUS results to minimize this distress and promote patient understanding (42).

\section{Management of High-Risk Population with a Genetic Predisposition}

The NCCN genetic high-risk guidelines include screening and risk-reduction recommendations based on the absolute lifetime risk for established genes, and the level of evidence demonstrating elevated risk. Other management guidance has also been put forth by the American Society of Clinical Oncology, American Society for Radiation Oncology, and Society of Surgical Oncology - Management of Hereditary Breast Cancer (43).

There are approximately 15 genes linked to an increased female breast cancer risk based on the NCCN genetic breast cancer guidelines (17). This handful of genes will vary in the magnitude of absolute lifetime risk, and genes can be categorized into 3 groups as high risk, moderate risk, and increased risk. The NCCN defines these ranges as over $60 \%, 41-60 \%$, and $15-40 \%$, lifetime risk respectively.

Recommendations are gene specific but can differ based on their breast cancer history or family history. High-risk breast screening recommendations include earlier screening initiation, along with more frequent clinical breast examination and imaging than for the average risk population. For example, women with a pathogenic variant in BRCA1 are in the high-risk category, with cumulative lifetime risk for breast cancer of $72 \%$ along with $44 \%$ risk for ovarian cancer to age 80 (44) (Table 2). BRCA1 positive women should begin clinical breast exams and breast MRI with contrast at age 25. Annual mammograms are added at age 30 , with alternating imaging modality every 6 months. Risk-reducing breast surgery should be discussed, though the recommended 
age of bilateral mastectomies is not set for unaffected women. BRCA1 positive women have $40 \%$ contralateral breast cancer risk for 20 years following a breast cancer diagnosis. Due to high ovarian cancer risk, bilateral salpingo-oophorectomy (BSO) is recommended between ages 35-40. BSO has the added benefit of breast cancer risk-reduction for women choosing high-risk screening rather than risk-reducing breast surgery. All women with a history of breast cancer should be given the option of germline testing, which may lead to modifying the management plan for women currently undergoing treatment. BRCA1 pathogenic variants also impart an increased risk for pancreatic cancer adenocarcinoma. Annual screening at age 50 is recommended if there is a first- or second-degree relative with a history of pancreatic cancer.

The high-risk disorder Li Fraumeni Syndrome (LFS) is due to PVs in TP53. Screening for LFS includes clinical breast exams and breast MRI at age 20, and mammograms at 30 due to the risk of young breast cancer (Table 2). This syndrome imparts a high risk for multiple sites of cancer including adrenocortical carcinoma, sarcomas, and central nervous system malignancies. Because of the various risks with LFS, a detailed protocol including breast imaging is followed for LFS. Individuals with genetic disorders like HBOC and LFS benefit when seen by a medical team with experience and expertise in managing hereditary breast cancer (45).

There are multiple moderate risk genes, each with different lifetime risk estimates (defined earlier as a 41-60\% lifetime risk) and accompanying cancer risks beyond breast cancer. Moderate risk genes call for a similar increased breast screening regimen as detailed for the high-risk genes, but do not typically have high enough breast cancer risks to recommend risk-reduction such as a mastectomy unless there is also a significant family history. Contralateral breast cancer risk varies between the moderate risk genes. Some genes impart an increased risk while others do not show higher risk for contra- lateral diagnosis than for a gene-negative individual. Most notable of these are the moderate risk genes CHEK2 and ATM (Table 2). For both of these genes, annual mammogram and breast MRI are recommended beginning at age 40 or earlier if younger diagnosed breast cancer is present in the family. Other risks associated with these genes should also be noted. For example, CHEK2 is also associated with colorectal cancer risk and ATM with pancreatic cancer risk (46).

Increased risk genes (sometimes called limited evidence genes) have a higher risk for breast cancer than the general population but may not be as high as the moderate or highrisk genes (15-40\% lifetime risk for breast cancer). Some examples of these genes include the BRIP1 and BARD1 genes. Information on the specific cancers and risks for these genes are still being determined at this time. These genes have variable management guidance: some may follow some of the increased breast screening guidelines outlined above, while others may not have official screening guidelines established (47).

Regardless of the risk classification of a gene, all genes may have particular variants that are commonly seen (CHEK2 1100delC) as well as other variants known to carry an unusually low risk (CHEK2 p.Ile157Thr) or higher risk (ATM c.7271T $>\mathrm{G}$ ) compared to usual for that gene. Further, new PRS are aiming to pinpoint an individual's cancer risk due to a known susceptibility gene such as CHEK2 (48). Another consideration is that genes found on many breast cancers MGPs can be associated with homozygous disorders including Ataxia Telangiectasia (ATM) and Fanconi Anemia (BRCA1, BRCA2, and PALB2).

\section{Management of High-Risk Population Without a Genetic Predisposition}

Women can be considered at a high risk for breast cancer based on their empiric risk for breast cancer (as determined by one of the above-mentioned models) even without having 
a genetic predisposition to cancer. According to the American Cancer Society (ACS) Guidelines, women with a lifetime risk for breast cancer of $>20-25 \%$ by the Claus, TC, or BRCAPro models are eligible for being screened with annual MRIs in addition to annual mammograms. These MRIs should begin at an age when they would normally start their annual mammograms (at age 40, or 10 years prior to the youngest age of onset of breast cancer in their family). Abbreviated MRI and CT mammography are two novel methods that have been gaining momentum in the field of breast cancer screening, although not yet adopted as a standard of care. Ultrasound is another modality that is useful as an adjunct to mammography, particularly in younger women and women with dense breasts. The ACS recommends adding ultrasounds in addition to mammograms in specific subgroups of people: particularly those with a significantly increased risk $(>20 \%$ lifetime risk) of breast cancer and/or dense breasts.

Improved screening and close monitoring have been shown to downstage breast cancer at diagnosis and has allowed for the diagnosis of breast cancer prior to lymph node involvement. However, ideally once high-risk individuals are identified, they should be treated with preventive measures that are safe and effective.

Several drugs are currently approved for breast cancer reduction in women under the age of 60 with a 5 -year risk of $1.7 \%$ based on the Gail model assessment. Those drugs include Selective Estrogen Receptor Modulators (SERMS) like tamoxifen and raloxifene (49). Large, randomized trials have demonstrated the effectiveness of aromatase inhibitors like exemestane, anastrozole, and letrozole in this setting (50). These drugs decrease the risk of breast cancer by $40-60 \%$, but they do come at a price: both SERMs have been linked to an increased risk of thromboembolic events, decreased libido, and depression. And when considering aromatase inhibitors, one must also consider the risks associated with these drugs like osteoporosis, myalgias, arthralgias, and cardiovascular sequelae. When prescribing those medications, providers need to involve patients in this shared decision by weighing the risks and benefits.

Other modifiable risk factors can play a role in decreasing breast cancer risk. Catsburg et al. evaluated close to 50,000 women via questionnaires on their adherence to cancer prevention guidelines outlined in the ACS Guidelines on nutrition and physical activity (51). Those guidelines included body mass index (BMI) goals of 18.5-25, physical activity 150-210 $\mathrm{min} /$ week, less red meat, more vegetables, and limiting alcohol. When women followed all those recommendations, breast cancer risk decreased by $31 \%$ compared to those following one guideline or less. It is helpful to discuss with patients extensively the option of chemoprevention as well as guide them to adopt a healthier lifestyle.

\section{Conclusion}

In conclusion, risk stratifying breast cancer in patients can lead to effective preventive therapies in hopes of improving cancer outcomes. This has been compared to the practice in cardiology of screening lipid profiles to treat with statins to decrease cardiovascular events. However, applying this to breast cancer remains challenging. We propose a two-step personalized approach to each woman presenting to a high-risk clinic.

The first step consists of individual risk stratification into one of three subgroups using genetic testing and empiric risk model calculations: average/slightly increased risk, high risk, or higher risk. The average/slightly increased risk subgroup includes women without a significant family history and no additional risk factors and who have a general population risk for breast cancer (typically a risk under $20 \%$ ). The higher risk subgroup is usually defined as having a 50-80\% lifetime risk for breast cancer and typically includes women with a genetic predisposition to cancer, like a BRCA1/2 mutation. The high risk group accounts for women whose risk falls in between these two subgroups (20-50\%) due to family history, moderate risk genes, or additional risk factors. 
The second step involves formulating recommendations based on the above risk subgroup. A woman in the average/slightly increased risk group still has a risk for breast cancer, and recommendations include annual screening and adopting a healthy lifestyle. The high-risk population meets criteria for increased breast cancer imaging (which may include ultrasounds and/or MRIs in addition to mammograms) as well as chemoprevention and a healthy lifestyle. It is crucial, however, to identify women who fall into the higher risk subgroup as these women should not only pursue the recommendations outline for the high risk group but may also be candidates for surgical intervention.

This is not a perfect system, and there are shortcomings to using an oversimplified model. Medical decision-making does require attention not just to individual risk factors, but also to the community where each woman lives and the resources she can access, and we recommend that regardless of which subgroup a woman falls into, that her individual needs and risks be accounted for.

Many questions remain unanswered in the world of personalized breast cancer risk assessment: are we over diagnosing and over treating patients? Are we unnecessarily creating more anxiety in our patients by pursuing increased screening, or contributing to screening fatigue? Should we test all women with a comprehensive genetic testing panel or focus on testing only those that meet criteria? Can we put a price tag on the importance of genetic testing? With more research, it is hopeful that biomarkers, genomic profiles, and tissue characteristics will help identify women who will benefit from more intense screening and preventive interventions and perfect a personalized screening approach for breast cancer.

\section{Conflict of Interest}

All authors declare no conflicts of interest.

\section{References}

1. Ahmad A. Breast Cancer Statistics: Recent Trends. Adv Exp Med Biol. 2019;1152:1-7.

2. Torre LA, Bray F, Siegel RL, Ferlay J, Lortet-Tieulent J, Jemal A. Global cancer statistics, 2012. CA Cancer J Clin. 2015;65(2):87-108.

3. Ji P, Gong Y, Jin ML, Hu X, Di GH, Shao ZM. The Burden and Trends of Breast Cancer From 1990 to 2017 at the Global, Regional, and National Levels: Results From the Global Burden of Disease Study 2017. Front Oncol. 2020 May 12;10:650.

4. Nelson HD, Fu R, Cantor A, Pappas M, Daeges M, Humphrey L. Effectiveness of Breast Cancer Screening: Systematic Review and Metaanalysis to Update the 2009 U.S. Preventive Services Task Force Recommendation. Ann Intern Med. 2016;164(4):244-55.

5. Niell BL, Freer PE, Weinfurtner RJ, Arleo EK, Drukteinis JS. Screening for Breast Cancer. Radiol Clin North Am. 2017;55(6):1145-1162.

6. Partovi S, Sin D, Lu Z, Sieck L, Marshall H, Pham R, Plecha D. Fast MRI breast cancer screening - Ready for prime time. Clin Imaging. 2020;60(2): 160-168.

7. Sun YS, Zhao Z, Yang ZN, Xu F, Lu HJ, Zhu ZY, Shi W, Jiang J, Yao PP, Zhu HP. Risk Factors and Preventions of Breast Cancer. Int J Biol Sci. 2017; 13(11):1387-1397.

8. Rojas K, Stuckey A. Breast Cancer Epidemiology and Risk Factors. Clin Obstet Gynecol. 2016;59(4):651-672.

9. Claus EB, Risch N, Thompson WD. Autosomal dominant inheritance of early-onset breast cancer. Implications for risk prediction. Cancer. 1994; 73(3):643-51.

10. McCarthy AM, Guan Z, Welch M, Griffin ME, Sippo DA, Deng Z, et al. Performance of Breast Cancer Risk-Assessment Models in a Large Mammography Cohort. J Natl Cancer Inst. 2020;112(5):489-497.

11. van Asperen CJ, Jonker MA, Jacobi CE, van Diemen-Homan JEM, Bakker E, Breuning $\mathrm{MH}$, et al. Risk estimation for healthy women from breast cancer families: new insights and new strategies. Cancer Epidemiol Biomarkers Prev. 2004;13(1):87-93.

12. Gail MH, Brinton LA, Byar DP, D K Corle, Green SB, Schairer C, et al. Projecting individualized probabilities of developing breast cancer for white females who are being examined annually. J Natl Cancer Inst. 1989; 81(24):1879-86.

13. Tyrer J, Duffy SW, Cuzick J. A breast cancer prediction model incorporating familial and personal risk factors. Stat Med. 2004;23(7):1111-30.

14. Mavaddat N, Michailidou K, Dennis J, Lush M, Fachal L, Lee A, et al. Polygenic Risk Scores for Prediction of Breast Cancer and Breast Cancer Subtypes. Am J Hum Genet. 2019;104(1):21-34. Epub 2018 Dec 13.

15. Berry DA, Iversen ES Jr, Gudbjartsson DF, Elaine H Hiller, Judy E Garber, Beth N Peshkin, et al. BRCAPRO validation, sensitivity of genetic testing of BRCA1/BRCA2, and prevalence of other breast cancer susceptibility genes. J Clin Oncol. 2002;20(11):2701-12.

16. Boggs DA, Rosenberg L, Adams-Campbell LL, Palmer JR. Prospective approach to breast cancer risk prediction in African American women: the black women's health study model. J Clin Oncol. 2015;33(9):1038-44.

17. Daly MB, Pal T, Berry MP, Buys SS, Dickson P, Domchek SM, et al. Genetic/Familial High-Risk Assessment: Breast, Ovarian, and Pancreatic, Version 2.2021, NCCN Clinical Practice Guidelines in Oncology. J Natl Compr Canc Netw. 2021;19(1):77-102.

18. Lincoln SE, Kobayashi Y, Anderson MJ, Yang S, Desmond AJ, Mills MA, et al A Systematic Comparison of Traditional and Multigene Panel Testing for Hereditary Breast and Ovarian Cancer Genes in More Than 1000 Patients. J Mol Diagn. 2015;17(5):533-44.

19. Fecteau H, Vogel KJ, Hanson K, Morrill-Cornelius S. The evolution of cancer risk assessment in the era of next generation sequencing. J Genet Couns. 2014;23(4):633-9.

20. Facio FM, Lee K, O'Daniel JM. A genetic counselor's guide to using nextgeneration sequencing in clinical practice. J Genet Couns. 2014;23(4):455-62.

21. LaDuca H, Polley EC, Yussuf A, Hoang L, Gutierrez S, Hart SN, et al. A clinical guide to hereditary cancer panel testing: evaluation of genespecific cancer associations and sensitivity of genetic testing criteria in a cohort of 165,000 high-risk patients. Genet Med. 2020;22(2):407-415. 
22. Myriad Timeline - https://myriad.com/about-myriad/inside-myriad/company-milestones/

23. Yadav S, Reeves A, Campian S, Paine A, Zakalik D. Outcomes of retesting BRCA negative patients using multigene panels. Fam Cancer. 2017;16(3): 319-328.

24. Lundy MG, Forman A, Valverde K, Kessler L. An investigation of genetic counselors' testing recommendations: pedigree analysis and the use of multiplex breast cancer panel testing. J Genet Couns. 2014;23(4):618-32.

25. Fecteau H, Vogel KJ, Hanson K, Morrill-Cornelius S. The evolution of cancer risk assessment in the era of next generation sequencing. J Genet Couns. 2014;23(4):633-9.

26. Kurian AW, Hughes E, Handorf EA, Gutin A, Allen B, Hartman AR et al. Breast and Ovarian Cancer Penetrance Estimates Derived from Germline MultipleGene Sequencing Results in Women. Precision Oncology - published online June 27, 2017.

27. LaDuca H, Polley EC, Yussuf A, Hoang L, Gutierrez S, Hart SN, et al. A clinical guide to hereditary cancer panel testing: evaluation of genespecific cancer associations and sensitivity of genetic testing criteria in a cohort of 165,000 high-risk patients. Genet Med. 2020;22(2):407-415. Epub 2019 Aug 13.

28. Buys SS, Sandbach JF, Gammon A, Patel G, Kidd J, Brown KL, et al. A study of over 35,000 women with breast cancer tested with a 25-gene panel of hereditary cancer genes. Cancer. 2017;123(10):1721-1730.

29. Couch FJ, Shimelis H, Hu C, Hart SN, Polley EC, Na J, et al. Associations Between Cancer Predisposition Testing Panel Genes and Breast Cancer. JAMA Oncol. 2017; 3(9):1190-1196.

30. Antoniou AC, Casadei S, Heikkinen T, Barrowdale D, Pylkäs K, Roberts J, et al. Breast-cancer risk in families with mutations in PALB2. N Engl J Med. 2014;371(6):497-506

31. Susswein LR, Marshall ML, Nusbaum R, Vogel Postula KJ, Weissman SM, Yackowski $L$, et al. Pathogenic and likely pathogenic variant prevalence among the first 10,000 patients referred for next-generation cancer panel testing. Genet Med. 2016;18(8):823-32.

32. Soegaard M, Jensen A, Frederiksen K, Høgdall E, Høgdall C, Blaakaer J, Kjaer SK et al. Accuracy of self-reported family history of cancer in a large case-control study of ovarian cancer. Cancer Causes Control. 2008;19(5): 469-79.

33. Ozanne EM, O'Connell A, Bouzan C, Bosinoff P, Rourke T, Dowd D, et al Bias in the reporting of family history: implications for clinical care. J Genet Couns. 2012;21(4):547-56.

34. Shah PD, Domchek SM. The contemporary landscape of genetic testing and breast cancer: Emerging issues. Breast J. 2020;26(8):1549-1555.

35. Chapman-Davis E, Zhou ZN, Fields JC, Frey MK, Jordan B, Sapra KJ, et al. Racial and Ethnic Disparities in Genetic Testing at a Hereditary Breast and Ovarian Cancer Center. J Gen Intern Med. 2021;36(1):35-42.

36. Canedo JR, Miller ST, Myers HF, Sanderson M. Racial and ethnic differences in knowledge and attitudes about genetic testing in the US: Systematic review. J Genet Couns. 2019:28(3):587-601.

37. Williams CD, Bullard AJ, O'Leary M, Thomas R, Redding 4th TS, Goldstein
K. Racial/Ethnic Disparities in BRCA Counseling and Testing: a Narrative Review. J Racial Ethn Health Disparities. 2019;6(3):570-583.

38. Slavin TP, Manjarrez S, Pritchard CC, Gray S, Weitzel JN. The effects of genomic germline variant reclassification on clinical cancer care. Oncotarget. 2019;10(4):417-423.

39. Scherr CL, Lindor NM, Malo TL, Couch FJ, Vadaparampil ST. Genetic counselors' practices and confidence regarding variant of uncertain significance results and reclassification from BRCA testing. Clin Genet. 2015;88(6):523-9.

40. Eccles BK, Copson E, Maishman T, Abraham JE, Eccles DM. Understanding of BRCA VUS genetic results by breast cancer specialists. BMC Cancer. 2015;15:936.

41. Vears DF, Sénécal K, Borry P. Genetic health professionals' experiences returning results from diagnostic genomic sequencing to patients. J Genet Couns. 2020;29(5):807-815

42. van Dijk S, Otten W, Tollenaar RA, van Asperen CJ, Tibben A. Putting it all behind: long-term psychological impact of an inconclusive DNA test result for breast cancer. Genet Med. 2008;10(10):745-50

43. Tung NM, Boughey JC, Pierce LJ, Robson ME, Bedrosian I, Dietz JR, et al. Management of Hereditary Breast Cancer: American Society of Clinical Oncology, American Society for Radiation Oncology, and Society of Surgical Oncology Guideline. J Clin Oncol. 2020;38(18):2080-2106.

44. Hamdi Y, Soucy P, Kuchenbaeker KB, Pastinen T, Droit A, Lemacon A, et al. Association of breast cancer risk in BRCA1 and BRCA2 mutation carriers with genetic variants showing differential allelic expression: identification of a modifier of breast cancer risk at locus 11q22.3. Breast Cancer Res Treat. 2017;161(1):117-134. Epub 2016 0ct 28.

45. Schon K, Tischkowitz M. Clinical implications of germline mutations in breast cancer: TP53. Breast Cancer Res Treat. 2018;167(2):417-423.

46. Stucci LS, Internò V, Tucci M, Perrone M, Mannavola F, Palmirotta R, et al. The ATM Gene in Breast Cancer: Its Relevance in Clinical Practice. Genes (Basel). 2021;12(5):727.

47. Filippini SE, Vega A. Breast cancer genes: beyond BRCA1 and BRCA2. Front Biosci (Landmark Ed). 2013:18:1358-72.

48. Gallagher S, Hughes E, Wagner S, Tshiaba P, Rosenthal E, Roa BB, et al. Association of a Polygenic Risk Score With Breast Cancer Among Women Carriers of High- and Moderate-Risk Breast Cancer Genes. JAMA Netw Open. 2020;3(7):e208501.

49. Vogel VG, Costantino JP, Wickerham DL, Cronin WM, Cecchini RS, Atkins $\mathrm{JN}$, et al. National Surgical Adjuvant Breast and Bowel Project (NSABP). Effects of tamoxifen vs raloxifene on the risk of developing invasive breast cancer and other disease outcomes: the NSABP Study of Tamoxifen and Raloxifene (STAR) P-2 trial. JAMA. 2006; 295(23):2727-41.

50. Goss PE, Ingle JN, Alés-Martínez JE ; NCIC CTG MAP.3 Study Investigators. Exemestane for breast-cancer prevention in postmenopausal women. $\mathrm{N}$ Engl J Med. 2011;364(25):2381-91.

52. Catsburg $\mathrm{C}$, Miller $\mathrm{AB}$, Rohan $\mathrm{TE}$. Adherence to cancer prevention guidelines and risk of breast cancer. Int J Cancer. 2014;135(10):2444-52. 